\title{
On-the-Ground Wisdom About Care Integration
}

\author{
Kurt C. Stange, $M D, P b D$, Editor \\ Ann Fam Med 2014;375-377. doi: 10.1370/afm.1682.
}

T The online discussion that accompanies each article published in Annals tremendously enriches the published work. These TRACK (Topical Response to the Annals Community of Knowledge) comments interpret the published articles in the context of what else is known and how the new information might be applied.

Comments published online since the last issue shed light onto research and care for people with multiple chronic conditions, a proposed role definition for family physicians, the integration of mental health and primary care, the use of the family history in health care in the age of information systems and genomics, and other topics around the generation and application of new knowledge. The quotations and summary comments below give a flavor of this rich conversation.

\section{ROLE DEFINITION FOR FAMILY PHYSICIANS 1}

"Most other specialties and medical disciplines are defined by organ systems, technologies or narrow demographic definitions of their target population." ${ }^{2}$

"... being a family physician is about the relationship with the patient and family, and does not depend on a certain set of procedures. We are defined by who we are more than by what we do. Or better yet, what we do is defined by who we are." ${ }^{13}$

"For there is no one role, one definition of the family physician $_{i}$ we are a collection whose careers respond to the needs of our families, communities, and personal interests, and will never conform to a job description or salary line that others have prescribed for us."

"Where are solid, reliable words like "generalist," "friendship," "personal responsibility," and "relationship." Substituting "enduring partnerships" brings to mind a business contract that concludes when our mutual self-interests have been satisfied. Relationships—we know too well-have no such endings. Patients look to us for opinions, guidance, and authority in the face of their paralyzing circumstance. Many seek our company when medical interventions are no longer helpful or desired. And those in greatest need-the marginalized members of society-would never know a partnership were it not for our ethical obligation to reach out to them." ${ }^{4}$ "...family doctors are generalist-trained, relationshipcentered, and community-oriented. We believe that conversation, friendship, and hope can transform lives. Our approach to patient care is governed by the moral imperative to always do the right thing." ${ }^{4}$

"Phillips and others are right to suggest that family doctors take a leading role in health care redesign. Our current disadvantage derives not so much from the failure of present leadership as from our collective silence. The authors also deserve credit for rekindling a critical discussion about how we think about ourselves as family doctors. Thought turns to serious talk about values, motivation, and a practical wisdom that can be plowed back into the practice of our profession. Words matter. Let's choose them carefully, share stories that bind us, and create the kind of workspace that allows us to effectively care for all those we love." ${ }^{4}$

"Quality defined as a bucket of process and disease metrics misses too much of what drives Triple Aim outcomes and consumes our time and resources chasing small measures while major outcome drivers are given lip service or no service at all. There is strong convergence between what consumers want from health care, ${ }^{5}$ the drivers of Triple Aim outcomes, ${ }^{6}$ and this definition of our role as family physicians." ${ }^{17}$

\section{THE COMPLEXITY OF CONTEXTUALIZING RESEARCH, POLICY, AND CARE FOR PEOPLE WITH MULTIPLE CHRONIC CONDITIONS ${ }^{8}$}

"After 15 years of practice in rural family medicine, one of my daily work experiences is feeling the squeeze between the rock of practice guidelines and the hard place of how my patients want to live their lives. Often, my patients make health-related decisions based on personal considerations far more than the advice of expert panels or research results. I'm most unsuccessful at "treating to target" when my best advice contradicts a life story."

"In the course of a regular day, I frequently find myself overlaying 4 to 10 practice guidelines in order to capture the screening and treatment measures that apply to a single person. But which interventions are more important, and when recommendations conflict how do we choose? At what point does the sum of burdens from the interventions outweigh the benefit? I'm currently serving as an on-the-fly integrator, stitching together multiple disease-based recommendations 
to try to represent what's best for the real person in front of me. Clinicians and the communities we serve will welcome a research approach that reframes the questions, as recommended in this article. I look forward to researchers learning what strategies are likely to achieve what goals for whole people across the course of their lives. Every day in clinic I work hard to channel our collective knowledge into meaningful positive change in an individual patient's life. My patients and I could really use some help navigating the complicated, multifaceted real world in which we find ourselves." ${ }^{19}$

"Advancing the research agenda means changing the way that we view evidence. Narrowly specified questions with narrowly specified interventions and narrowly specified outcomes in unrealistic environments are far less useful than realist evaluations that incorporate context in the interpretation of results. We also need new designs to allow for and rigorously evaluate the effect of adaptive trials where interventions are not fixed in the protocol but can adapt to become more effective when gaps and failures are detected early in the trial. Rigorous evaluations of qualityimprovement approaches are needed. This also requires changing accepted definitions of rigor from reductionist to more expansive realist approaches."10

"... a contextual approach shifts the focus from categorical disease to the individual and, most important, the range of factors that affect individuals as part of their everyday lives. The contextual approach is very much in keeping with an ecological perspective that is becoming the standard framework for research in population health."11

"...it should be possible to expand the unit of investigation and analysis from the "individual" to the "family" itself."

"...expanding the definition of multimorbidity to include the entire spectrum of conditions, whether, acute, recurrent, or of long-term duration, and examining patterns of health states rather than clusters of single diseases, would likely result in a better understanding of the characteristics and outcomes of multi-contextual factors in patients with multiple health needs."12

"...understanding the clinical and social complexity that is at the heart of caring for whole people, free-range humans living in families and neighborhoods and cultural tapestries. It makes one-disease-at-a-time RCT's and clinical guidelines seem almost quaint."13

"...the complex, non-linear interactions that occur between these "multiple chronic conditions" and the "many contextual factors", but I wonder if that really captures the nuance and the flavor of these interactions... it is a huge step forward to include family and neighborhood-level contextual factors in any research designed to improve health outcomes. However, we cannot stop at counting and measuring social factors, or treating them as lists of independent covariates in a regression equation. Rather, these factors are merely ingredients in the complex (and flavorful!) stew that is borne of whole people in relationship with families and neighborhoods and culture. ${ }^{13}$
Noticing flavors (nuanced interactions and subtleties) is even more important at the community level as we work to achieve optimal and equitable health outcomes for all. Some communities are making great progress toward overcoming racial-ethnic and socioeconomic health disparities-how are they doing it? What are the ingredients and flavors that create a distinctive taste of health equity at the community level? More importantly, what interventions could transform the historically-bitter ingredients and flavors of a highdisparity community into the savory boldness of a highequity community?" 13

"One way to focus on people and not their diseases is to focus on goals (life extension, quality of life, growth and development, and a good death) and then look for ways to help them to reach them. Chronic conditions can sometimes interfere with these goals or they may not. Another way to understand this new paradigm is to focus on prioritization. To rationally prioritize, one needs to understand the goals of the endeavor." ${ }^{\prime 14}$

\section{INTEGRATION OF MENTAL HEALTH AND PRIMARY CARE ${ }^{15,16}$}

The discussion of integrating behavioral health into patient-centered medical homes ${ }^{17}$ includes a rich discussion from a listserv of people with diverse expertise in behavioral / primary care practice integration. ${ }^{18}$ The combination of insights from deep on-the-ground implementation experience and from knowledge of the research and clinical literature points to next steps at the practice, community and policy levels.

A related discussion ${ }^{19}$ provides important insights into the nuances of using motivational interviewing to foster shared decision making and patient-centered care. ${ }^{20}$ Mauksch favors "...combining goal oriented practice with collaborative, curious problem solving, infused with the spirit of motivational interviewing." ${ }^{21}$

\section{AUTOMATING INITIAL FAMILY HISTORY GATHERING SO THAT IT CAN BECOME CENTRAL TO PRACTICE ${ }^{22}$}

"Family history as the primary approach to identify possible genetic risk in primary care is still paramount." ${ }^{123}$

"The process of acquiring a family history can be as simple as asking, 'How's the family?' or as complex as constructing a 3-generation pedigree supported by evidence from medical records." 24

"...with this highly useful tool, we should more boldly revisit and push the US Surgeon General's Family Health History Initiative and reintroduce the importance of family history to the nation's doctors, nurses, health care organizations and patients. ${ }^{25}$ 


\section{BUILDING BLOCKS FOR PRIMARY CARE PRACTICE ${ }^{26}$}

A group of 3rd-year medical students provides analysis of the building blocks for high-performing primary care. ${ }^{27,28}$

Experienced family physician, David Loxterkamp provides other insights:

"The biggest (stumbling) block of the PCMH may be its unintended consequence: that within it, we lose sight of the nature and value of our work even as we gain proficiency in doing the job. The distinction between "work" and "job" is nowhere more beautifully unveiled than in a 1989 essay by G. Gayle Stephens. ${ }^{29}$ Our job entails the use of instruments to treat disease and measure outcomes of care the work involves caring for patients who approach us in pain, despair, dependence, or grief. ... Because they have chosen us, we stay with them and *occasionally* witness the rarest of all miracles-personal transformation — and celebrate it, no matter how small or transient the change.

So we might ask, ... does the model attract and nurture doctors of activism, compassion and commitment? ...Will we fill our newly engineered homes with physicians who put "emphasis on individual relationships, the challenge of tackling whatever problem a patient presents, and the potential for creating social change through our work?" "30 $^{30}$

We invite readers to enrich your understanding of Annals articles by perusing the TRACK discussion, and to contribute to the shared learning by adding your insights.

\section{References}

1. Phillips RL, Brundgardt S, Lesko SE, et al. The future role of the family physician in the United States: a rigorous exercise in definition. Ann Fam Med. 2014;12(3):250-255.

2. Schwenk TL. Why do we have so much trouble understanding who we are [eletter]? Ann Fam Med. http://annfammed.org/content/12/3/250/reply\#annalsfm_el_27641, 13 June 2014.

3. Scherger JE. Re: An excellent and useful definition [eletter]. Ann Fam Med. http://annfammed.org/content/12/3/250/reply\#annalsfm_ el_27595, 27 May 2014.

4. Loxterkamp DA. Words matter- a response to the RDG definition [eletter]. Ann Fam Med. http://annfammed.org/content/12/3/250/ reply\#annalsfm_el_27359, 19 May 2014.

5. Bechtel C, Ness DL. If you build it, will they come? Designing truly patient-centered health care. Health Aff (Millwood). 2010;29(5): 914-920.

6. Macinko J, Starfield B, Shi L. Quantifying the health benefits of primary care physician supply in the United States. IntJ Health Serv. 2007;37(1):111-126.

7. Moore LG. An excellent and useful definition [eletter]. Ann Fam Med. http://annfammed.org/content/12/3/250/reply\#annalsfm_ el_27335, 15 May 2014.

8. Bayliss EA, Bonds DE, Boyd CM, et al. Understanding the context of health for persons with multiple chronic conditions: moving from what is the matter to what matters. Ann Fam Med. 2014;12(3): 260-269.

9. Dillon KG. Between a rock and a hard place [eletter]. Ann Fam Med. http://annfammed.org/content/12/3/260/reply\#annalsfm_el_27725, 20 June 2014.

10. Wodchis WP. Addressing complexity [eletter]. Ann Fam Med. http:// annfammed.org/content/12/3/260/reply\#annalsfm_el_27702, 19 June 2014.
11. Satariano WA. Multiple chronic conditions and the health of families [eletter]. Ann Fam Med. http://annfammed.org/ content/12/3/260/reply\#annalsfm_el_27629, 2 June 2014.

12. Shadmi E, Reid RJ, Weiner JP. Multimorbidity in the context of disparities [eletter]. Ann Fam Med. http://annfammed.org/content/12/3/260/reply\#annalsfm_el_27598, 27 May 2014.

13. Rust GS. From factors to flavors [eletter]. Ann Fam Med. http:// annfammed.org/content/12/3/260/reply\#annalsfm_el_27584, 27 May 2014.

14. Mold J. Goal-directed health care [eletter]. Ann Fam Med. http:// annfammed.org/content/12/3/260/reply\#annalsfm_el_27366, 19 May 2014.

15. Kathol RG, deGruy FV, Rollman BL. Value-based financially sustainable behavioral health components in patient-centered medical homes. Ann Fam Med. 2014;12(3):172-175.

16. Baird M, Blount A, Brungardt S, et al. The development of joint principles: integrating behavioral health care into the patientcentered medical home. Ann Fam Med. 2014; 12(3):183.

17. Replies to Kathol RG, deGruy FV, Rollman BL. Ann Fam Med. 2014; 12(3):172-175. http://www.annfammed.org/content/12/2/172/reply.

18. Niebauer L, Reed FM, deGruy F, et al. Ongoing reader conversation about behavioral health components, including author responses (from the Advancing Care Together listserv) [eletter]. Ann Fam Med. http://www.annfammed.org/content/12/2/172/reply\#annalsfm_ el_27237, 25 April 2014.

19. Replies to Elwyn G, Dehlendorf C, Epstein RM, Marrin K, White J، Frosch DL. Ann Fam Med. 2014;12(3):270-275. http://annfammed. org/content/12/3/270/reply.

20. Elwyn G, Dehlendorf C, Epstein RM, Marrin K, White J, Frosch DL. Shared decision making and motivational interviewing: achieving patient-centered care across the spectrum of health care problems. Ann Fam Med. 2014;12(3):270-275.

21. Mauksch LB. Confusion in practice and in the literature [eletter]. Ann Fam Med. http://annfammed.org/content/12/3/270/ reply\#annalsfm_el_27333, 15 May 2014.

22. Emery JD, Reid G, Prevost AT, Ravine D, Walter FM. Development and validation of a family history screening questionnaire in Australian primary care. Ann Fam Med. 2014;12(3):241-249.

23. Pace W. Family history made simple [eletter]. Ann Fam Med. http:// www.annfammed.org/content/12/3/241/reply\#annalsfm_el_27321، 15 May 2014.

24. Williams JK. Promising family history screening questionnaire [eletter]. Ann Fam Med. http://www.annfammed.org/content/12/3/241/ reply\#annalsfm_el_27728, 20 June 2014.

25. David SP. Finally - a family history we can really use [eletter]. http:// www.annfammed.org/content/12/3/241/reply\#annalsfm_el_27330, 15 May 2014.

26. Bodenheimer T, Ghorob A, Willard-Grace R, Grumbach K. The 10 building blocks of high-performing primary care. Ann Fam Med. 2014;12(3):166-171.

27. Montavon B, Khazaei S, Baker M, et al. Medical student perspective of the 10 building blocks of high-performing primary care [eletter]. http://annfammed.org/content/12/2/166/reply\#annalsfm_el_27058, 9 April 2014.

28. Ayers M, Joseph S, Curtis T, et al. Re: medical student perspective of the 10 building blocks of high-performing primary care [eletter]. http://annfammed.org/content/12/2/166/reply\#annalsfm_el_27313, 15 May 2014

29. Stephens GG. Family medicine as counterculture. Fam Med. 1989; 21(2):103-109.

30. Loxterkamp DA. Stepping stone or stumbling block: the PCMH and the future of family medicine [eletter]. Ann Fam Med. http://www. annfammed.org/content/12/2/166/reply\#annalsfm_el_27051, 8 April 2014. 